\title{
List of Abbreviations for Books by Stanley Hauerwas
}

(Not a comprehensive list of all books authored, coauthored, or edited by Hauerwas)

vV Vision and Virtue: Essays in Christian Ethical Reflection (Notre Dame, IN: Fides Publishers, Inc., 1974).

CCL Character and the Christian Life: A Study in Theological Ethics (San Antonio, TX: Trinity University Press, 1975). 2d ed., with a new introduction, 1985.

TT Truthfulness and Tragedy: Further Investigations in Christian Ethics (Notre Dame, IN: University of Notre Dame Press, 1977).

CC A Community of Character: Toward a Constructive Christian Social Ethic (Notre Dame, IN: University of Notre Dame Press, 1981).

PK The Peaceable Kingdom (Notre Dame, IN: University of Notre Dame Press, 1983).

AN Against the Nations: War and Survival in a Liberal Society (Minneapolis, MN: Winston Press, Inc., A Seabury Book, 1985). This book is now published by UNDP.

SP Suffering Presence: Theological Reflections on Medicine, the Mentally Handicapped, and the Church (Notre Dame, IN: University of Notre Dame Press, 1986).

CET Christian Existence Today: Essays on Church, World, and Living in Between (Durham, NC: Labyrinth Press, 1988).

RA Resident Aliens: Life in the Christian Colony, with William Willimon (Nashville, TN: Abington Press, 1989).

NS Naming the Silences: God, Medicine, and the Problem of Suffering (Grand Rapids, MI: Eerdmans, 1990). This book was reissued in 1993 under the title God, Medicine, and the Problem of Suffering.

AC After Christendom: How the Church Is to Behave If Freedom, Justice, and a Christian Nation Are Bad Ideas (Nashville, TN: Abington Press, 1991).

us Unleashing the Scriptures: Freeing the Bible from Captivity to America (Nashville, TN: Abington Press, 1993). 
DF Dispatches from the Front: Theological Engagements with the Secular (Durham, NC: Duke University Press, 1994).

IGC In Good Company: The Church as Polis (Notre Dame, IN: University of Notre Dame Press, 1995).

WRAL Where Resident Aliens Live: Exercises for Christian Practice, with William Willimon (Nashville, TN: Abington Press, 1996).

CAV Christians among the Virtues: Theological Conversations with Ancient and Modern Ethics, with Charles Pinches (Notre Dame, IN: University of Notre Dame Press, 1997).

ww Wilderness Wanderings: Probing Twentieth-Century Theology and Philosophy (Boulder, CO: Westview Press, 1997).

sтT Sanctify Them in the Truth: Holiness Exemplified (Nashville, TN: Abington Press, 1998).

TG The Truth about God: The Ten Commandments in Christian Life, with William Willimon (Nashville, TN: Abington Press, 1999).

PPS Prayers Plainly Spoken (Grand Rapids, MI: Brazos Press, 1999).

BH A Better Hope: Resources for a Church Confronting Capitalism, Postmodernity, and America (Grand Rapids, MI: Brazos Press, 2000).

WGU With the Grain of the Universe: The Gifford Lectures for 2001 (Grand Rapids, MI: Brazos Press, 2001). 